The $5^{\text {th }}$ International Conference on Family Business and Entrepreneurship

\title{
ISLAMIC FINANCIAL LITERACY AND MANAGEMENT FOR MSMES
}

\author{
Imam Suseno $^{1^{*}, \text { Larisa Yohanna }^{2} \text {, Endang Sondari }}{ }^{3}$ \\ ${ }^{1,2,3}$ Faculty of Language and Art, University of Indraprasta PGRI Jakarta, \\ Corresponding author: susenoblr@gmail.com
}

\begin{abstract}
The Financial Services Authority Indonesia (OJK) survey has been released, that the financial literacy rate of Indonesian people. The OJK is classified aproximatelly $29.7 \%$, which is considered well literature. Low financial literacy and its products cause people, especially MSMEs, to be easily caught up in lucrative short-term investments without considering the risks faced later on. The low financial literacy for MSMEs is also due to the lace of knowledge and attitudes towards Islamic financial institutions in Indonesia which are the pillars of the national economy. This research aims to reveal the level of Islamic financial literacy and financial management of Sharia for SMEs. The research approach utilizes a descriptive quantitative. The researchers use questioner, in-depth interviews, and field observations as their data. The data is taken in June-August 2021. The respondents, who are associated with the OKe Oce organization, is located in Kuningan-West Java, Jakarta, and Surabaya-East Java, and are selected randomly. The research results show: (1) The level of Islamic financial literacy of MSME actors is mostly at the level of less less literate, (2) Financial management of MSME actors is still not ideally organized and runs professionally, and (3) there are three pillars of increasing Islamic financial literacy: promotions/campaigns, strengthening the Islamic financial literacy infrastructure, and Structuring/services the Islamic finance industry properly. MSME actors must be convinced that transacting with Islamic financial institutions can improve their welfare based on sharia principles that are halal and profitable.
\end{abstract}

Keywords: Islamic financial literacy, Sharia financial management, and MSMEs.

\section{Introduction}

Financial difficulties are one of the problems that are often faced by humans. This can be caused by errors in financial management, credit management and lack of financial planning, as well as knowledge of financial literacy that has not been maximized. Thus, each individual must have the knowledge and skills to manage their personal financial resources effectively for welfare. In the current globalization era, it could be seen as the rise of the world economy. Globalization has various positive and even negative impacts, one of which is in the economic growth of a country. Economic growth is the most powerful instrument for reducing poverty and improving the quality of life in developing countries. Economic growth is a development of activities in the economic field. Financial difficulties are one of the problems that are often faced by humans. This can be caused by errors in financial management, credit management and lack of financial planning, as well as knowledge of financial literacy that has not been maximized. Thus, each individual must have the knowledge and skills to manage their personal financial resources effectively for welfare. The increasing of the number of goods and services produced by the community, indicates a continuous process of changing the economic conditions of a country, towards a better state over a certain period. Economic growth can be used as a benchmark in the success of an economy and economic 
development in a country. The contribution of economic actors has an important role. The increase in national income cannot be separated from the contribution of MSME actors. Most of the economic actors are SMEs that are developing. This is in accordance with the statement of Ndiaye et al (2018), that the small and medium business sector plays an important role for the economy throughout the world, especially developing countries. In addition, small and medium enterprises, would act as a medium to distribute the development results that have been achieved.

Currently, MSMEs have become a fundamental foundation for the Indonesian economy. The development of the number of MSMEs is increasing every year. Government support for MSMEs has also experienced positive developments in terms of financing and interest. The development in 2016, the interest on loans for SMEs was 9\% and the government plans to reduce the interest in the following years (Julianto, 2016). Bank Indonesia Press Release (2017), MSMEs are seen as positive contributors to the national economy because: (a) the population of business actors is very dominant (99\%), and (b) provides services for basic needs of the community, the multiplier effect is high geographically spread throughout country in all sectors. Thus, this can be said as an instrument of income distribution and reducing inequality in people's welfare, (c) MSMEs are also used as for the creation of new entrepreneurs, and (d) Creating a dependency relationship in a minimal import component, by utilizing raw materials and local resources so that save foreign exchange. Every year, the increasing of UMKM steadily increased. So, it should bring an advanced condition, like the need for financing by MSME actors would automatically increase both to maintain the smooth running of the business and for business development. They certainly need financing with an easy and fast process. Bank financial institutions with the principle of prudence in loan processing will take a long time because they have to go through several procedures and analysis of loan eligibility for creditors. This makes SME players perceive that bank lending is difficult and convoluted. Borrowing for new entrepreneurs is very difficult, because they collide with the requirements for business financial reporting in every two years.

Chandra (2016) explained that: "MSME actors often find it difficult to get credit from Bank Financial Institutions because of the difficult requirements that must be met to get credit". MSME actors would be looking for other alternatives such as borrowing from other financial institutions with easier terms, so that they can apply for loans to get additional business capital. The Ministry of Cooperatives and SMEs (2016) stated "to avoid more and more MSME actors applying for credit/loans to many parties (other financial institutions), the government seeks to increase financial access to the community, as well as encourage financial inclusion so that they can get access to KUR (People's Business Credit". In-addition this problems also explained by Purnama \& Yuliafitri, (2019: 32), who said that "The delay in the country's economic development is due to the lack of access to financial institutions, so that many people are trapped in the crime mode of selling financial products". The large number of Muslim population in Indonesia is not proportional to the number of Muslims who understand Islamic financial service products. In 2016 OJS (Financial Services Authority) released the results of a national survey and financial inclusion that the level of public financial literacy which is classified as well literature is only $29.7 \%$. The low level of public knowledge about the financial industry and its products causes people to be easily trapped in making investments that offer lucrative profits in the short term without considering the risks. This causes harm to the community, instead.

The performance of MSMEs in Indonesia is still relatively low compared to other ASEAN countries, especially in terms of productivity, export contribution, global and regional production participation and contribution to added value. The low competitiveness of MSMEs in Indonesia is partly due to low levels of education and expertise, difficulty in obtaining permits for MSMEs, lack of access to capital, and lack of infrastructure support. Community welfare is one of the tools for the success of the state in carrying out development. The first is seen from the macroeconomic aspect, such as Islamic financial literacy. Sharia financial literacy provides benefits as: (a) the more people's desire to save and invest in Sharia, it is hoped that the economy will be stable, because the Islamic financial system strictly prohibits usury. Financial economic stability will encourage exports and investment, (b) the more people desire to use Islamic financial service institutions funds, the real sector growth, (c) the increasing public desire to use Islamic financial services, then the national economy will be more robust and stronger from the impact of the global crisis storm, (d) the increasing number of people, who are well literate in Islamic finance, the more the number of users of Islamic financial products and services, so that it will create equity (justice) and welfare, (e) the increasing the number of people, who save and invest through Islamic finance, it is hoped that the 
sources of funds for development will increase, (f) the increasing number of people, who use funds from Islamic financial service institutions, it is hoped that intermediation in the financial sector will be even greater.

Financial literacy is one of the strategic programs for the government and the community in realizing that people and SMEs are literate about financial services. Various countries continue to encourage financial literacy to become a national program to increase the prosperity and welfare of their people, by paying attention to the benefits of financial literacy owned by MSME actors to increase business in the future.

A person is considered as well literate, when he orshe has the ability and confidence to implement that knowledge when making decisions. Acordong to Chaulagain (2015) in Aisha, (2019). Combining an understanding of everyday situations such as insurance, credit, savings, and loans Financial behavior has an important role in the financial decision-making process. Decision making with financial behavior can be interpreted as the process of selecting certain investment alternatives from a number of alternatives. Behavioral finance paradigm suggests that investment decision is influenced in a large proportion by psychological and emotional factors. this case is related to Ramona Birau, (2013, 45), told that "Human emotional complexity includes the following primary feelings: fear, panic, anxiety, envy, euphoria, greed, satisfaction, ambition or vanity"

Islamic financial literacy as one of the indicators that affect financial satisfaction, so the higher the level of Islamic financial literacy a person, the higher the level of financial satisfaction. Base on that, Nurhasyriani (2019) mentioned, that "therefore it is expected that each individual to improve Sharia financial literacy that can be obtained from socialization or seminars by the government, universities, the surrounding environment, and so on"

The development of Islamic finance in Indonesia is quite proud, positive achievements from institutional aspects and supporting infrastructure, regulatory tools. This is also observed by Amelia, Princess and Firmansyah, Rahayu $(2017,107)$. supervision, awareness and literacy of the community to its services. so many other countries are learning to develop Islamic finance from Indonesia Therefore, this study reveals how the level of financial literacy of Islamic financial management funds for MSME actors in various cities in Indonesia?.

\section{Literature Review}

Regarding financial literacy, Purnama \& Yuliafitri $(2019,32)$ stated that "Financial literacy is a series of processes and activities to increase knowledge, confidence, skills of consumers and the wider community so that they are able to manage finances more efficiently. good". While Remund (2010: 279) states five categories of conceptual definitions of financial literacy: (1) knowledge of financial concepts, (2) ability to communicate about financial concepts, (3) dexterity in managing personal finances, (4) ability in make the right financial decisions, (5) the ability to plan effective future finances according to needs. This is reinforced by the statement of Huston, S.J (2010: 311), which states "Personal financial literacy is the ability to read, analyze, manage and communicate about the personal financial condition that effects material well-being. It includes the ability to discern financial choices, discuss money and financial issues without (or despite) discomfort, plan for future and respond competently to life events that effect everyday financial decisions, including events in the general economy". The Financial Services Authority in 2013 is of the opinion that education in order to improve finance is needed, the level of financial literacy can be classified as follows:

1. Well literate (21.84\%); namely having knowledge and confidence about financial service institutions. In addition, financial service products, including features, benefits and risks, rights and obligations related to financial products and services, as well as having skills in using financial products and services.

2. Sufficient literate (75.69\%); have knowledge and belief about financial service institutions and financial products and services, including features, benefits and risks, rights and obligations related to financial products and services.

3. Less literate $(2.06 \%)$; only have knowledge of financial service institutions, financial products and services. 
4. Not literate $(0.41 \%)$; do not have knowledge and confidence in financial service institutions and financial products and services, and do not have skills in using financial products and services. (https://www.ojk.go.id, accessed August 2019).

Related to this, OJK sees that increasing financial literacy has long-term goals for all segments of society, like: (a) The increasing of people's ability in finance literacy. Those people previously less literate or not literate to become well literate, (b) Increasing the number of users of financial products and services. In order for the wider community to determine financial products and services that suit their needs, the public must properly understand the benefits and risks, know their rights and obligations and believe that the selected financial products and services can improve people's welfare. For the community, financial literacy provides great benefits, such as: (a) Being able to choose and utilize financial products and services that suit their needs; have the ability to do better financial planning, (b) Avoid investing in unclear financial instruments. Gain an understanding of the benefits and risks of financial products and services. Financial institutions and the community need each other so that the higher the level of public Financial Literacy, the more people will take advantage of financial products and services.

For the community, financial literacy provides great benefits, such as: (a) Being able to choose and utilize financial products and services that suit their needs; have the ability to do better financial planning, (b) Avoid investing in unclear financial instruments. Gain an understanding of the benefits and risks of financial products and services. Financial institutions and the public need each other so that the higher the level of public Financial Literacy, the more people will take advantage of financial products and services. Related this, Ramona Birau (2013) also explained that investment decisions are influenced mostly by psychological and emotional factors. This is reinforced by the statement of Arifin, (2018), which says that financial knowledge and financial attitudes have a positive influence on financial behavior. In addition, behavioral finance mediates the relationship between financial knowledge and attitudes towards financial satisfaction.

From the quotations above, it can be seen that the positive impact of financial literacy on the demand for bank credit is more pronounced for the younger and more educated population. Individuals with higher financial literacy also tend to have formal savings accounts. The higher demand for formal financial services is positively driven by the availability of publicly disseminated information. This is explained by Soedarmono \& Prasetyantoko (2017), that it describes formal financial services, which highlights the importance of expanding public awareness programs on financial literacy and financial inclusion throughout Indonesia. For those who have a higher level of financial literacy, they tend to save and plan for retirement, indicating that an increase in financial literacy can have an effect on behavior change (Lusardi, 2009). Individuals who have more financial knowledge will certainly choose cheaper mortgages and avoid high interest payments and additional fees (Gerardi, et al., 2010); (Lusardi \& Tufano, 2009); (Moore, 2003)

\section{Research Method}

This descriptive quantitative research was carried out during September-October 2021 when Indonesia imposed restrictions on social activities during the COVID-19 pandemic, so that in the process of collecting research data from various MSME actors in several areas, namely Jakarta, Kuningan, Yogyakarta, and Surabaya, 245 respondent data were collected. who have filled out online and paper-based questionnaires. According to Moleong (2006: 6) the type of qualitative research is to understand the phenomena experienced by research subjects by utilizing various natural methods. This study also uses a descriptive approach. According to Azwar (2010: 7), descriptive research aims to describe situations and events systematically and accurately with facts and characteristics regarding a particular population or field. The population or sample of this research was carried out in the MSME sector in the Kuningan area market, West Java. Data collection techniques using observation, questionnaires or questionnaires. 
Table 1. Variable Operational

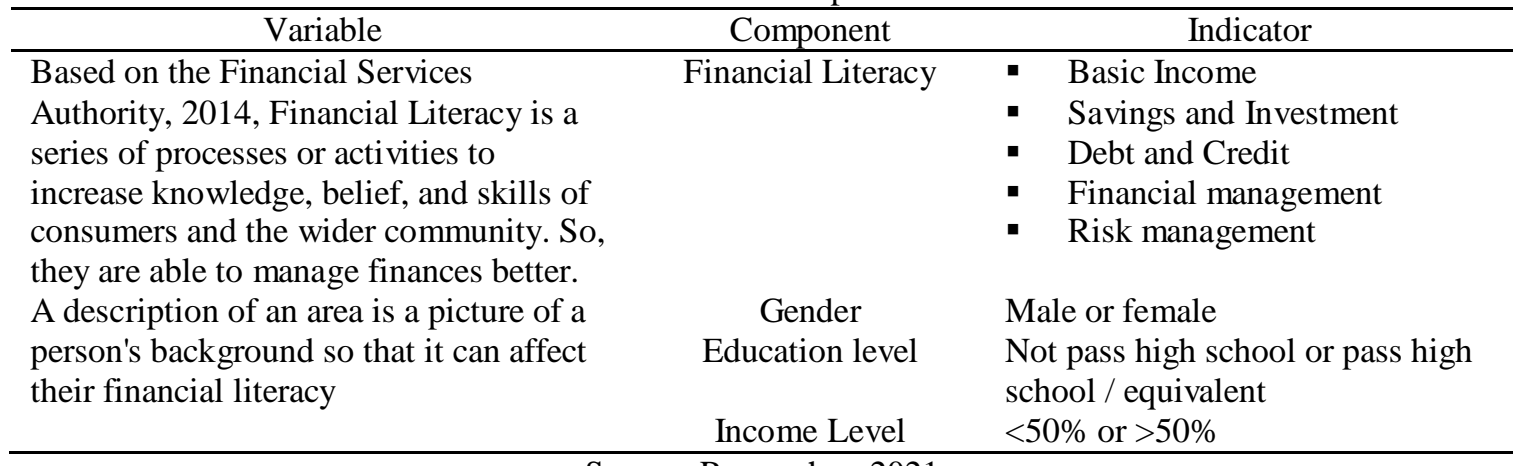

The steps of this research are as follows:

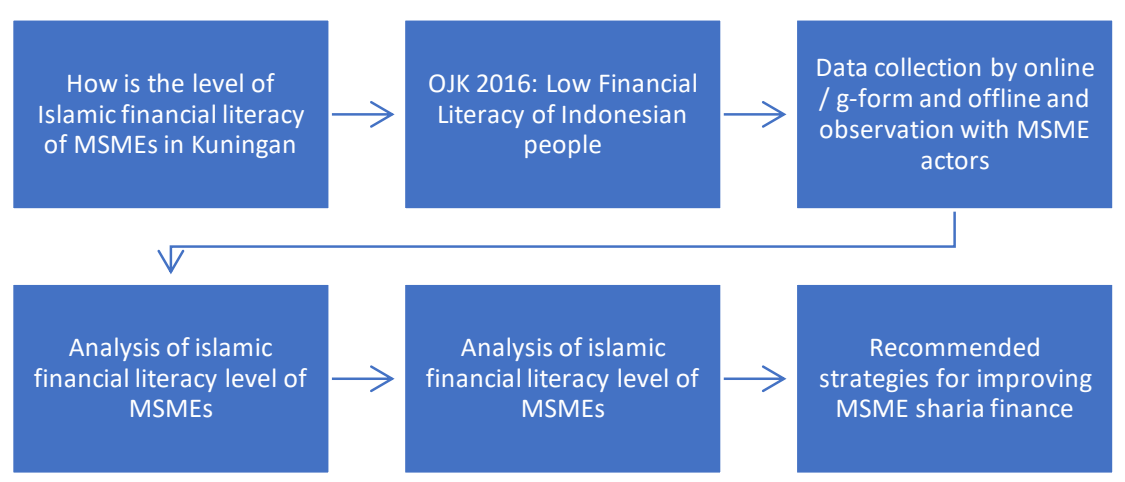

Figure 1. Research framework

(Source: Researcher, 2021)

\section{Results and Discussion}

In this research, the researchers aim to determine the level of financial literacy of micro, small and medium enterprises (MSMEs). In this research, data analysis would like to reveal indicators of financial literacy and Islamic financial behavior for MSME actors. The implementation of data collection is still during the COVID-19 pandemic, so that the interview and observation were only able to comb through respondents who were in several areas Kuningan-West Java, Jakarta, and Surabaya-East Java.As the research data. There are 245 responden MSME actors

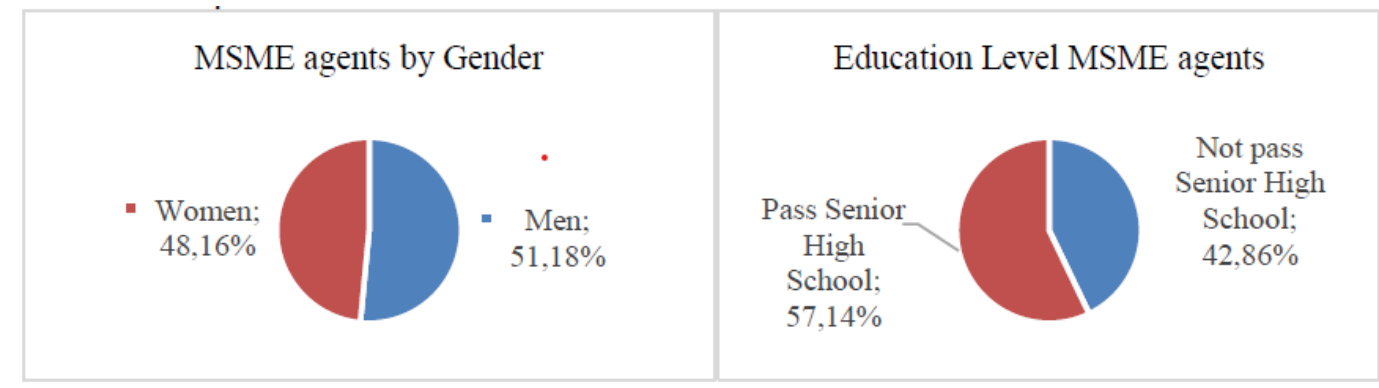

Figure 2. MSME Actors by Gender and Education Level

(Source: Primary data September-October 2021)

In the research 245 MSMEs in were known to be mostly approximately, males $51.18 \%$ and then female, approximately $48.16 \%$. The thinness of this gender comparison shows that the role of women is increasing in efforts to boost the economy among the brass community. Then from the gender comparison can also be

80

(c) 2021. The $5^{\text {th }}$ International Conference on Family Business and Entrepreneurship. 
seen from that MSMEs most of the $57.14 \%$ have completed secondary education, and some others $42.86 \%$ did not finish high school.

The types and businesses of the respondents who were able to approach and conduct interviews varied widely from trading various snacks, fruit and fruit juices, various clothes, basic necessities, and so on. During the COVID-19 pandemic, most of them felt dissatisfied with the business they were doing. The decline in business turnover and the declining purchasing power of the people were also due to the restrictions on social activities by the government which further worsened the income of MSME actors.

The types and businesses of the respondents who were able to approach and conduct interviews varied widely from trading in various snacks, fruit and fruit juices, various clothes, basic necessities, and so on. During the COVID-19 pandemic, most of them felt dissatisfied with the business they were doing. The decline in business turnover and the declining purchasing power of the people were also due to the restrictions on social activities by the government which further worsened the income of MSME actors.

Satisfaction with business results as MSME actors reached 93\% who were not satisfied and the remaining $7 \%$ stated that they were quite persistent. Judging from the age aspect of MSME actors, they are classified as being in the productive age, namely between the ages of 25 and 40 years, as much as $65 \%$. This means that the productive age will be able to develop over time, the business developed can be better and bigger in the future. The time span of the business, which the respondents have been involved in, is shown in the following table:

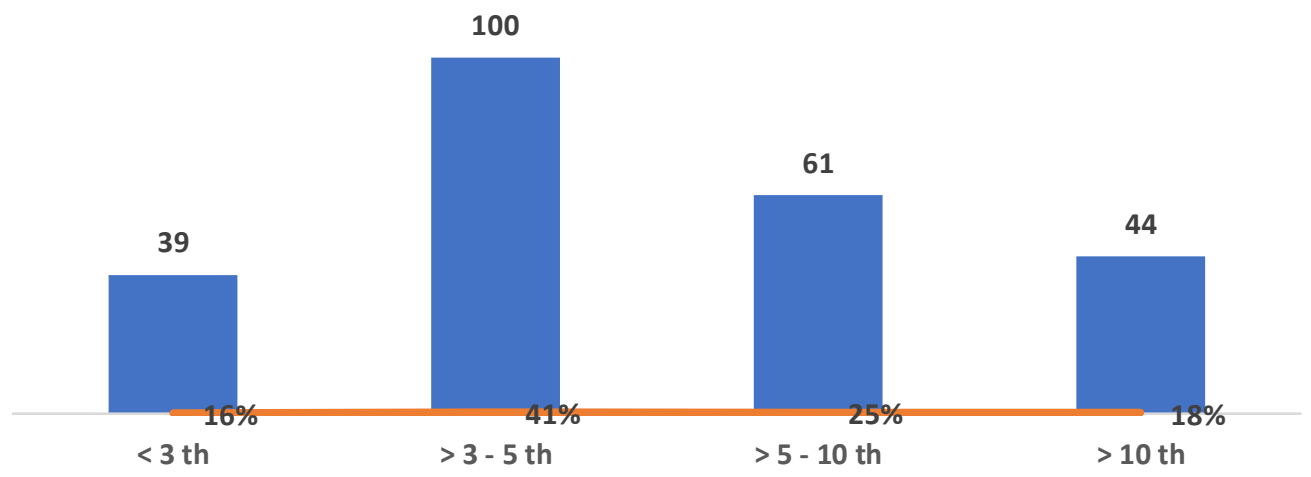

Figure 3. Business Age of MSME Actors

(Source: Primary Data September-October 2021)

The length of business is also an indicator of the consistency of the business run by the respondent. The longer the age of the business shows the business is able to make a profit so that it can survive to this day. So that in carrying out their business the respondents are assisted by several employees, including:

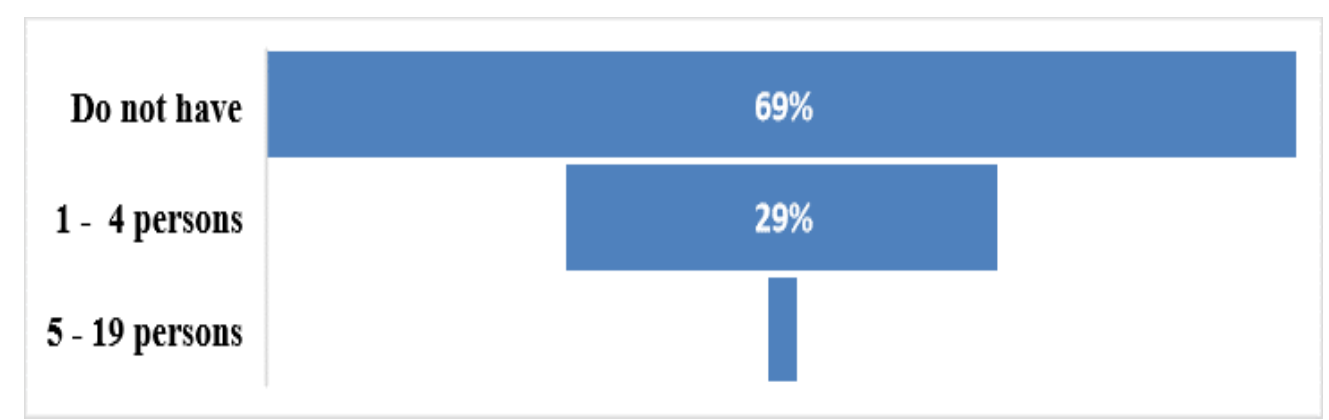

Figure 4. Number of Employees of MSME Actors

(Source: Primary Data September-October 2021)

Based on the information, respondents have the most employees between 1 to 4 people as much as $69 \%$, then $29 \%$ have no employees meaning they are still able to handle their own business, and $2 \%$ have employees between 5 to 19 people. MSME actors in several regions stated that before the Covid-19 social restrictions were carried out every month they still received business benefits. Maintaining a business 
requires a very hard effort and lowering profit margins. Most stated that they are still trying to maintain business continuity. The level of Islamic financial literacy of MSME actors encountered by the researchers showed various levels of ability as follows:

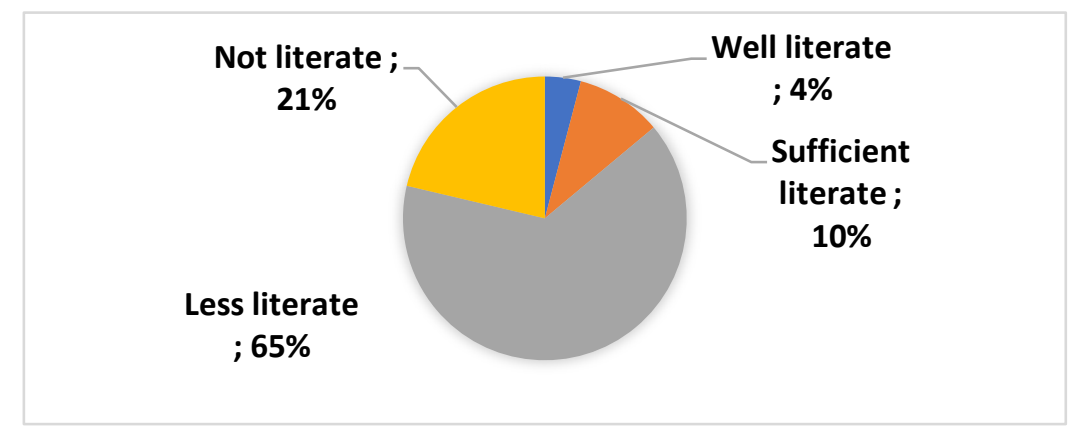

Figure 5. Level of Islamic Financial Literacy of MSME Actors

(Source: Primary Data September-October 2021)

Based on the data above, the result are:

- Well literate (4\%); namely having knowledge and confidence about financial service institutions and sharia financial service products, including features, benefits and risks, rights and obligations related to sharia financial products and services, as well as having skills in using sharia financial products and services.

- Sufficient literate (10\%); have knowledge and belief about financial service institutions and Islamic financial products and services, including features, benefits and risks, rights and obligations related to Islamic financial products and services.

- Less literate (65\%); only have knowledge of financial service institutions, Islamic financial products and services.

- Not literate (21\%); do not have knowledge and confidence in financial service institutions and Islamic financial products and services, and do not have skills in using Sharia financial products and services.

The results of the analysis related to the pattern of financial management for MSME actors also had a negative impact from the COVID-19 pandemic situation, where the pattern of financial management became unorganized. This was detected from several aspects of the questions on the instrument answered by the respondents, including:

- Knowledge of MSME entrepreneurs on financial management is also not good enough. It is obtained information that $78 \%$ have never read/participated in seminars/workshops on business financial management, and only $22 \%$ have heard/read. So that all this time running the business he was involved in implementing self-taught financial management and or learning from experience gained from fellow MSME entrepreneurs. This shows that the financial planning aspect is not yet qualified as a business that can be well planned.

- The aspect of organizing business finances has also not gone well. Although as many as $43 \%$ of MSME entrepreneurs have neat financial records in their business as a form of self-evaluation of the business they do, and as many as $57 \%$ do not do financial documentation. The results of interviews with several MSME actors who organize business finances are unable to separate business finances from finances for personal interests, so that finances blend into one.

- Aspects of delegation of authority in the management of business finances cannot occur, because currently most of the MSME business operations are handled by themselves. Because during the COVID-19 pandemic, we no longer have employees to help with business operations.

- Aspects of business financial control for actors, still have efforts to continue to evaluate the course of the business even though it is not well documented. Optimism for the future hope of MSME actors as much as $90 \%$ have a plan to develop the business they are involved in, and $10 \%$ do not have a business development plan. However, the business plan to be developed has not been well organized, meaning that the estimates needed for business development are not yet available as an evaluation tool for MSME activities.

Therefore, efforts are needed to educate MSME actors so that they are able to run a business with a name, be comfortable and avoid usury behavior which will clearly harm the continuity of their business. Strategies to improve or educate the public to understand Islamic financial products through increasing literacy of 
MSME actors can be through the Islamic financial literacy movement through three pillars, including:

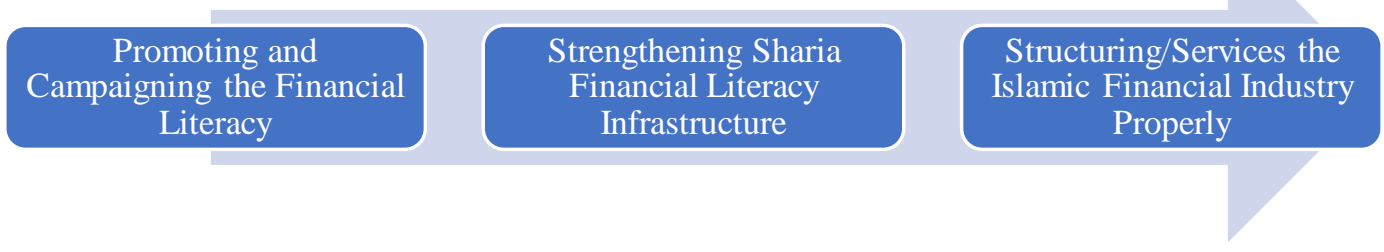

Figure 6. Three Pillars Financial Literacy Movement

(Source: Adaptation of Purnama \& Yuliafitri, 2019)

Through three pillars: (1) promoting education programs and national financial literacy campaigns, (2) strengthening financial literacy infrastructure with a fast Islamic industrial sector, and (3) the sizeable Muslim population in Indonesia, this has an impact on the importance of Islamic financial literacy for introducing Islamic financial products to the public (Purnama \& Yuliafitri, 2019: 3). The program to increase Islamic financial literacy for the community must have the following principles: (a) inclusive: covering all groups of people, (b) systematic and measurable: financial literacy is delivered in a programmatic, easy to understand, simple manner, and its achievements can be measured, (c) ease of use access: financial services and information are widely distributed throughout Indonesia and easily accessible, and (d) collaboration: involve all stakeholders together in implementing financial literacy (Otiritas Jasa Keuangan, 2010). In the context of MSME actors, the benefits obtained by the program to increase Islamic financial literacy include: (a) MSMEs are able to choose and utilize Islamic financial products and services that are in accordance with their needs, (b) MSME actors can better carry out Islamic financial planning, ( c) MSME actors can avoid investing activities in illegal (bodong) financial instruments, (d) MSME actors get an understanding of the benefits and risks of Islamic financial products and services

\section{Conclusion and Implications}

Based on the results of the study concluded:

a. The level of Islamic financial literacy of MSME actors in several regions in Indonesia is mostly at the level of less less literate, namely having low knowledge of financial service institutions, Islamic financial products and services. Factors that influence Islamic financial literacy in the Kuningan, Answerarat area include age, type of gender, education, type of business, length of business, initial capital, source of capital, income, and number of employees. But only the length of effort and the number of employees that affect financial knowledge.

b. The financial management of MSME actors is still not ideally leading to the formation of a business that moves and runs professionally. Financial management is still the one between business finance and finance for personal interests.

c. Improving Islamic financial literacy for MSMEs can be done through three main pillars, namely (1) promotion/ campaign of Islamic financial literacy, (2) strengthening infrastructure for Islamic financial literacy, and (3) Structuring/services the Islamic financial industry properly. MSME actors must be convinced that the selected financial products and services can improve their welfare based on halal and profitable Sharia principles.

The results of this study have the following implications:

a. There needs to be a greater introduction of products from Islamic financial institutions to MSMEs in the brass city of West Java.

b. There needs to be sharia financial development and education to MSMEs so that they can avoid actions that can worsen investments that have been invested.

c. There needs to be an information channel or application of Islamic financial learning for MSMEs that is easy and accessible to anyone. 
d. Local governments need to always conduct supervision, coaching, and encourage MSMEs to be able to access existing Islamic financial institutions so that people's economic activities that can avoid various financial transactions that can worsen investment in the future.

\section{Acknowledgement}

The writers would like to gratefully acknowledge The Directorate General of Higher Education, Research and Technology, Ministry of Education, Culture, Research and Technology, for supporting research funding of the 2021 Leading Higher of Education Applied Research Scheme, with the title: "Application Design of Mobile Knowledge Management and Video Animation in Sharia Financial Literacy Enhancement". Appreciation and thanks also to LLDIKTI Region III Jakarta and the Institute of Research and Community Service-Universitas Indraprasta PGRI that have assisted this research activity through the Research Contract Number: 1248/LL3/PG/2021, $3^{\text {rd }}$ of March 2021, and the UNINDRA Research Agreement/Contract Number: 007/SKP.LT/LPPM/UNINDRA/2021, $29^{\text {th }}$ of March 2021.

\section{References}

Aisyah, Siti. (2019). Analisis Pengaruh Tingkat Literasi Keuangan terhadap Financial Attitude dan Financial Behavior. S1 thesis, STIE Indonesia Banking School http://lib.ibs.ac.id/index.

Amelia Manggala Putri, and Firmansyah, Rahayu. (2017). Optimalisasi laku pandai berbasis masjid guna literasi dan inklusi keuangan Syariah berkelanjutan. Jurnal Ekonomi dan Bisnis Islam, Vol.3 No. 2 Juli-Desember 2017.

Arifin, Zainul A. (2018). Influence factors toward financial satisfaction with financial behavior as intervening variable on Jakarta area workforce. European Research Studies Journal, XXI(1), 90103.

Chandra, Ardan Adhi. (2016). Sulit Dapat Kredit Perbankan, Pelaku UMKM Pinjam ke Banyak Pihak. https://finance.detik.com/bursa-dan-valas/d-3313844/sulit-dapat-kredit-perbankan-pelaku-umkmpinjam-ke-banyak-pihak. Diakses 20 Januari 2019.

Gerardi, K., Goette, L. \& Meier, S. (2010). Financial literacy and subprime mortgage delinquency: Evidence from a survey matched to administrative data, s.l.: Federal Reserve Bank of Atlanta.

Huston, S.J. (2010). Measuring Financial Literacy. Journal of consumer affair volume 44, no.2 (2010). P. 311.

Julianto, Pramdia Arhando. 2016.Tahun 2017, Suku Bunga Dana Bergulir untuk UKM Turun di Bawah 7 Persen. https://ekonomi.kompas.com/read/2016/10/20/140829926/tahun.2017. Diakses 20 Januari 2019.

Lusardi, A. \& Tufano, P., (2009). Debt Literacy, Financial Experiences, and Overindebtedness, s.l.:National Bureau of Economic Research.

Lusardi, A. (2009). U.S. Household Savings Behavior: The Role of Financial Literacy, Information and Financial Education Programs. In: C. Foote, L. Goette \& S. Meier, eds. Policymaking Insights fromBehavioral Economics,. s.1.:Federal Reserve Bank of Boston, pp. 109-149.

Moleong, Lexy J. (2006). Metode Penelitian Kualitatif. Bandung: Remaja Rosdakarya.

Moore, D., (2003). Survey of financial literacy in Washington state: knowledge, behaviour, attitudes and experiences, s.1.: Washington State University.

N. Ndiaye et al. (2018). Demystifying small and medium enterprises' (SMEs) performance in emerging and developing economices. Borsa Istambul Review 18-4 (2018) 269-281.

Nurhasyriani, Indah. (2019). Literasi keuangan Syariah terhadap kepuasan financial. Skripsi Pada Universitas Sumatera Utara. Medan.

Otoritas Jasa Keuangan. (2016). Salinan Peraturan Otoritas Jasa Keuangan Nomor 76/POJK.07/2016 tentang Peningkatan Literasi Keuangan dan Inklusi Keuangan di Sektor Jasa Keuangan bagi Konsumen dan/atau Masyarakat. Jakarta: Otoritas Jasa Keuangan.

Otoritas Jasa Keuangan, https://www.ojk.go.id (diakses Agustus 2019).

Ramona Birău, F. (2013). The Impact of Behavioral Finance on Stock Markets University of Craiova , Faculty of Economics and Business Administration, 78421(3), 45-50.

Remund, David L. (2010). Financial literacy expliced: the case for a clearer definition in an increasing complex economy. The Journal of consumer affairs, volume 44, no. 2. 2010, p. 279.

Soedarmono, W., \& Prasetyantoko, A. (2017). Financial Literacy and the Demand for Financial Services in Remote Areas: Evidence from Indonesia. Ssrn. https://doi.org/10.2139/ssrn.3000339. 
Purnama, Hani Meilita \& Yuliafitri, Indri. (2019). Efektivitas Gerakan literasi keuangan Syariah dalam mengedukasi masyarakat memahami produk keuangan Syariah. Banque Syar'I: Jurnal Ilmiah Perbankan Syariah, Volume 5 Nomor 1 Januari-Juni 2019.

Yudistira, Galvan. (2018). Bank menengah merasa sulit penuhi aturan rasio kredit UMKM. 20\%.https://keuangan.kontan.co.id/news/bank-menengah-merasa-sulit-penuhi-aturan-rasio-kreditumkm-20. Diakses 20 Januari 2019. 